\title{
Editorial: Memory T Cells: Effectors, Regulators, and Implications for Transplant Tolerance
}

\author{
Yu-Qun Zeng ${ }^{1}$, Chuanjian $L^{2 *}$ and Zhenhua Dai ${ }^{1 *}$ \\ ${ }^{1}$ Section of Immunology, Second Affiliated Hospital of Guangzhou University of Chinese Medicine, Guangdong Provincial \\ Academy of Chinese Medical Sciences, Guangzhou, China, ${ }^{2}$ Division of Dermatology, Second Affiliated Hospital of \\ Guangzhou University of Chinese Medicine, Guangdong Provincial Academy of Chinese Medical Sciences, \\ Guangzhou, China
}

Keywords: memory $\mathbf{T}$ cells, regulatory $\mathrm{T}$ cells, costimulation, migration, $\mathrm{T}$ cell metabolism, transplantation immunology

\section{The Editorial on the Research Topic}

Memory T Cells: Effectors, Regulators, and Implications for Transplant Tolerance

\section{OPEN ACCESS}

Edited by:
Frans Claas,
Leiden University Medical Center,
Netherlands
Reviewed by:
Jean Villard,
Switzerland
Takuya Ueno,
Geneva University Hospital,
Harvard Medical School, USA
*Correspondence:
Chuanjian Lu
luchuanjian888@vip.sina.com;
Zhenhua Dai
zdai2009@hotmail.com

Specialty section:

This article was submitted to Alloimmunity and Transplantation,

a section of the journal

Frontiers in Immunology

Received: 31 October 2015

Accepted: 11 January 2016

Published: 25 January 2016

Citation:

Zeng Y-Q, Lu C and Dai Z (2016)

Editorial: Memory T Cells: Effectors,

Regulators, and Implications for

Transplant Tolerance.

Front. Immunol. 7:7.

doi: $10.3389 /$ fimmu.2016.00007
Memory T-cells respond to previously encountered antigens more rapidly and vigorously than their naive counterparts. They are divided into three subsets: central memory, effector memory, and tissue-resident memory T-cells. They are somewhat resistant to immunosuppressive treatments and are generally believed to be a threat to transplant survival. However, mounting evidence has demonstrated that memory $\mathrm{CD} 8^{+} \mathrm{CD} 122^{+} \mathrm{T}$-cells with central memory cell phenotypes $\left(\mathrm{CD} 45 \mathrm{RA}^{-} \mathrm{CD} 44^{\text {high }}{ }^{\mathrm{CD}} 62 \mathrm{~L}^{\text {high }} \mathrm{CCR} 7^{+}\right)$can regulate T-cell homeostasis and suppress both autoimmune and alloimmune responses. Therefore, memory T-cells, especially CD $8{ }^{+} \mathrm{CD} 122^{+} \mathrm{T}$-cells, may respond as either aggressive memory or regulatory T-cells (Treg). This research topic may shed light on when they act as memory versus Treg cells, and how to target memory T-cells or otherwise utilize memory-like Tregs to promote long-term allograft survival.

Memory T-cells are considered to be a major barrier to long-term transplant survival or tolerance (1). Targeting allospecific T-cell memory appears to be required for transplant tolerance induction. Then, the question is whether blocking conventional T-cell costimulation would inhibit memory T-cell responses. Previous studies have shown that memory T-cells are resistant to CD40/CD154 costimulatory blockade $(2,3)$. It is also generally accepted that B7-CD28 costimulation is not required for memory T-cell activation (4). They are either less dependent on or totally independent of CD28 costimulation $(5,6)$. Therefore, it is likely that blocking B7-CD28 is insufficient for preventing allograft rejection in the face of memory T-cells. Perhaps that is why a high incidence of acute rejection of renal allografts, despite CTLA4-Ig treatments, has occurred in clinic due to the cross-reactivity of memory T-cells, derived from pathogen-specific immune responses, with an alloantigen (7). However, recent studies using animal models have shown that optimal elaboration of secondary T-cell responses is dependent on B7-CD28 interactions in the context of anti-infectious immunity (Ville et al.). Interestingly, selectively targeting CD28 with FR104 is more potent in suppression of allograft rejection than targeting CD80/86 with CTLA4-Ig (Ville et al.), suggesting that selective blockade of CD28 signaling alone presents an advantage of allowing immunoregulatory signals mediated by CTLA4. Furthermore, blocking OX- 40 costimulatory signal prolongs secondary heart allograft survival in the presence of CD40/CD40L and LFA-1/ICAM-1 blockade (8), indicating that additional blockade of OX-40 signaling is required for abrogating memory $\mathrm{T}$ cell responses.

Memory T-cells can rapidly trigger alloimmune responses (9). It has been known that early infiltration of $\mathrm{CD}^{+}$memory T-cells into allografts facilitates allograft rejection and presents 
a hurdle to achieving long-term allograft survival (10-12). Signaling pathways for memory T-cell migration to an inflamed graft include $\mathrm{G}$ protein-coupled chemokine receptor signaling and cognate antigen-engaged TCR signaling as both signals trigger downstream integrin activation (Zhang and Lakkis). Interestingly, cognate antigen presence is necessary for driving antigen-specific memory T-cell migration into the peripheral tissue even without acute inflammation (13). Blocking integrin with anti-LFA-1 or anti-VLA-4 mAb prevents memory T-cell migration to a graft, attenuates alloreactive memory T-cell recall responses, and suppresses allograft rejection $(14,15)$. However, indiscriminately blocking LFA-1, though preventing memory and effector T-cell migration, increases the chance of developing post-transplant EBV-associated lymphoproliferative diseases while targeting VLA-4 may result in reactivation of fatal infections (16). Therefore, it is important to seek new strategies, instead of the universal blockade of major chemokines, to prevent donor-specific memory T-cell migration without increasing the risk of infections. One potential strategy to do so is to target the inside-out signaling pathway downstream of the TCR but not chemokine receptors (Zhang and Lakkis), such as SKAP1, leading to the suppression of antigen-driven but not chemokine-driven memory T-cell migration to a graft.

Recently, there has been a renewed interest in immune metabolism in $\mathrm{CD}^{+} \mathrm{T}$-cells. Their proliferation and function require a metabolic adaptation to meet their needs for energy and biosynthesis (Yap et al.). Activated CD8 ${ }^{+} \mathrm{T}$-cells reprogram their metabolism from OXPHOS to aerobic glycolysis and glutaminolysis (17), supporting their rapid growth with sufficient energy as well as metabolic intermediates. Since glycolysis and glutaminolysis are two major metabolic pathways that are essential for $\mathrm{CD}^{+}$effector cell function, blocking metabolic pathways could lead to the discovery of new immunosuppressive drugs for preventing allograft rejection, although these approaches likely cause significant side effects. For instance, 2-Deoxy-D-glucose (2-DG) inhibits glycolysis by blocking hexokinase function and hence suppresses cytotoxic function of effector CD8 T-cells while blocking glutaminolysis

\section{REFERENCES}

1. Wu Z, Bensinger SJ, Zhang J, Chen C, Yuan X, Huang X, et al. Homeostatic proliferation is a barrier to transplantation tolerance. Nat Med (2003) 10:87-92. doi:10.1038/nm965

2. Zhai Y, Meng L, Gao F, Busuttil RW, Kupiec-Weglinski JW. Allograft rejection by primed/memory CD8+ T cells is CD154 blockade resistant: therapeutic implications for sensitized transplant recipients. J Immunol (2002) 169:466773. doi:10.4049/jimmunol.169.8.4667

3. Trambley J, Bingaman AW, Lin A, Elwood ET, Waitze S-Y, Ha J, et al. Asialo GM1+ CD8+ T cells play a critical role in costimulation blockade-resistant allograft rejection. J Clin Invest (1999) 104:1715-22. doi:10.1172/JCI8082

4. Sprent J, Surh CD. T cell memory. Annu Rev Immunol (2002) 20:551-79. doi:10.1146/annurev.immunol.20.100101.151926

5. Croft M, Bradley LM, Swain S. Naive versus memory CD4+ responses to antigen: memory cells are less dependent on accessory cell costimulation and respond to many antigen-presenting cell types including resting B cells. J Immunol (1994) 152:2675-85. with a glutamine antagonist 6-diazo-5-oxo-L-norleucine (DON) inhibits T-cell proliferation (Yap et al.). More studies are urgently needed to seek metabolic antagonists that are effective in immunosuppression but result in less severe side effects.

Previous studies have shown that $\mathrm{CD}^{+} \mathrm{CD} 122^{+} \mathrm{T}$-cells with central memory phenotypes regulate $\mathrm{T}$-cell homeostasis (18) while more recent data have suggested that they suppress conventional T-cell responses (18-24) and control autoimmune diseases $(25,26)$. We have found that memory $\mathrm{CD}^{+} \mathrm{CD} 122^{+}$ T-cells and bystander central memory $\mathrm{CD}^{+}$T-cells inhibit murine allograft rejection $(27,28)$. Moreover, others have shown that central memory $\mathrm{CD} 8{ }^{+} \mathrm{T}$-cells mediate lung allograft acceptance (29). Importantly, we have demonstrated that memory-like $\mathrm{CD}^{+} \mathrm{CD} 122^{+}$Tregs are more potent in their suppression of allograft rejection than their $\mathrm{CD} 4^{+} \mathrm{CD} 25^{+}$counterparts (30). Hence, not only are memory $\mathrm{CD} 8^{+} \mathrm{CD} 122^{+} \mathrm{T}$-cells regulatory cells, they can also boost the strength of Treg-mediated suppression. The exact mechanisms underlying their suppression are still not well understood, although $\mathrm{CD}^{+} \mathrm{CD} 122^{+}$Tregs may restrict immune responsiveness by production of IL-10, TGF $\beta 1$, and IFN $\gamma$. In order to utilize them in clinic transplantation, more extensive studies are required to fully understand their mechanisms of action and their safety. Furthermore, we have revealed that PD-1 expression on $\mathrm{CD}^{+} \mathrm{CD} 122^{+} \mathrm{T}$-cells is critical for their regulatory function. Therefore, memory-like CD ${ }^{+} \mathrm{CD} 122^{+} \mathrm{PD}-1^{+} \mathrm{T}$-cells could be one of the best Treg subsets for the induction of long-term allograft survival or tolerance. It remains to be determined whether this subset of Tregs can be expanded in vitro.

\section{AUTHOR CONTRIBUTIONS}

Y-QZ wrote primary draft, and CL and ZD edited the editorial.

\section{FUNDING}

This work was supported by Natural Science Foundation of China (NSFC 81471550).

6. London CA, Lodge MP, Abbas AK. Functional responses and costimulator dependence of memory CD4+ T cells. JImmunol (2000) 164:265-72. doi:10.4049/jimmunol.164.1.265

7. Vincenti F, Larsen C, Durrbach A, Wekerle T, Nashan B, Blancho G, et al. Costimulation blockade with belatacept in renal transplantation. N Engl J Med (2005) 353:770-81. doi:10.1056/NEJMoa050085

8. Dai H, Peng F, Lin M, Xia J, Yu S, Lan G, et al. Anti-OX40L monoclonal antibody prolongs secondary heart allograft survival based on CD40/CD40L and LFA- 1/ICAM-1 blockade. Transpl Immunol (2015) 32:84-91. doi:10.1016/j. trim.2015.01.001

9. Adams AB, Williams MA, Jones TR, Shirasugi N, Durham MM, Kaech SM, et al. Heterologous immunity provides a potent barrier to transplantation tolerance. J Clin Invest (2003) 111:1887-95. doi:10.1172/ JCI200317477

10. Schenk AD, Nozaki T, Rabant M, Valujskikh A, Fairchild RL. Donorreactive CD8 memory $\mathrm{T}$ cells infiltrate cardiac allografts within 24-h posttransplant in naive recipients. Am J Transplant (2008) 8:1652-61. doi:10.1111/j.1600-6143.2008.02302.x 
11. Koyama I, Nadazdin O, Boskovic S, Ochiai T, Smith RN, Sykes M, et al. Depletion of CD8 memory $\mathrm{T}$ cells for induction of tolerance of a previously transplanted kidney allograft. Am J Transplant (2007) 7:1055-61. doi:10.1111/j.1600-6143.2006.01703.x

12. Donckier V, Craciun L, Miqueu P, Troisi RI, Lucidi V, Rogiers X, et al. Expansion of memory-type CD8+ T cells correlates with the failure of early immunosuppression withdrawal after cadaver liver transplantation using high- dose ATG induction and rapamycin. Transplantation (2013) 96:306-15. doi:10.1097/TP.0b013e3182985414

13. Walch JM, Zeng Q, Li Q, Oberbarnscheidt MH, Hoffman RA, Williams $\mathrm{AL}$, et al. Cognate antigen directs $\mathrm{CD} 8+\mathrm{T}$ cell migration to vascularized transplants. J Clin Invest (2013) 123:2663-71. doi:10.1172/ JCI66722

14. Xia J, Chen J, Shao W, Lan T, Wang Y, Xie B, et al. Suppressing memory T cell activation induces islet allograft tolerance in alloantigen-primed mice. Transpl Int (2010) 23:1154-63. doi:10.1111/j.1432-2277.2010.01106.x

15. Page AJ, Ford ML, Kirk AD. Memory T-cell-specific therapeutics in organ transplantation. Curr Opin Organ Transplant (2009) 14:643-9. doi:10.1097/ MOT.0b013e328332bd4a

16. Vincenti F, Mendez R, Pescovitz M, Rajagopalan PR, Wilkinson $\mathrm{AH}, \mathrm{Butt} \mathrm{K}$, et al. A phase I/II randomized open-label multicenter trial of efalizumab, a humanized anti-CD11a, anti-LFA-1 in renal transplantation. Am $J$ Transplant (2007) 7:1770-7. doi:10.1111/j.1600-6143.2007.01845.x

17. Maclver NJ, Michalek RD, Rathmell JC. Metabolic regulation of $\mathrm{T}$ lymphocytes. Annu Rev Immunol (2013) 31:259-83. doi:10.1146/ annurev-immunol-032712-095956

18. Rifải M, Kawamoto Y, Nakashima I, Suzuki H. Essential roles of CD8+CD122+ regulatory $\mathrm{T}$ cells in the maintenance of $\mathrm{T}$ cell homeostasis. J Exp Med (2004) 200:1123-34. doi:10.1084/jem.20040395

19. Endharti AT, Rifa IM, Shi Z, Fukuoka Y, Nakahara Y, Kawamoto Y, et al. Cutting edge: $\mathrm{CD} 8+\mathrm{CD} 122+$ regulatory $\mathrm{T}$ cells produce IL-10 to suppress IFN-gamma production and proliferation of CD8+ T cells. J Immunol (2005) 175:7093-7. doi:10.4049/jimmunol.175.11.7093

20. Chen X, Priatel JJ, Chow MT, Teh HS. Preferential development of CD4 and CD8 T regulatory cells in RasGRP1-deficient mice. J Immunol (2008) 180:5973-82. doi:10.4049/jimmunol.180.9.5973

21. Shi Z, Rifái M, Lee YH, Shiku H, Isobe K, Suzuki H. Importance of CD80/CD86- CD28 interactions in the recognition of target cells by CD8+CD122+ regulatory $T$ cells. Immunology (2008) 124:121-8. doi:10.1111/j.1365-2567.2007.02747.x
22. Molloy MJ, Zhang W, Usherwood EJ. Suppressive CD8+ T cells arise in the absence of CD4 help and compromise control of persistent virus. J Immunol (2011) 186:6218-26. doi:10.4049/jimmunol.1003812

23. Endharti AT, Okuno Y, Shi Z, Misawa N, Toyokuni S, Ito M, et al. CD8+CD122+ regulatory $\mathrm{T}$ cells (Tregs) and CD4+ Tregs cooperatively prevent and cure CD4+ cell-induced colitis. J Immunol (2011) 186:41-52. doi:10.4049/jimmunol.1000800

24. Wang LX, Li Y, Yang G, Pang PY, Haley D, Walker EB, et al. CD122+CD8+ Treg suppress vaccine-induced antitumor immune responses in lymphodepleted mice. Eur I Immunol (2010) 40:1375-85. doi:10.1002/eji.200839210

25. Kim HJ, Wang X, Radfar S, Sproule TJ, Roopenian DC, Cantor H. CD8+ T regulatory cells express the Ly49 class I MHC receptor and are defective in autoimmune prone B6-Yaa mice. Proc Natl Acad Sci U S A (2011) 108:2010-5. doi:10.1073/pnas.1018974108

26. Mangalam AK, Luckey D, Giri S, Smart M, Pease LR, Rodriguez M, et al. Two discreet subsets of CD8 T cells modulate PLP(91-110) induced experimental autoimmune encephalomyelitis in HLA-DR3 transgenic mice. J Autoimmun (2012) 38:344-53. doi:10.1016/j.jaut.2012.02.004

27. Wan N, Dai H, Wang T, Moore Y, Zheng XX, Dai Z. Bystander central memory but not effector memory CD8+ T cells suppress allograft rejection. J Immunol (2008) 180:113-21. doi:10.4049/jimmunol.180.1.113

28. Dai H, Wan N, Zhang S, Moore Y, Wan F, Dai Z. Cutting edge: programmed death-1 defines CD8+CD122+ T cells as regulatory versus memory $\mathrm{T}$ cells. J Immunol (2010) 185:803-7. doi:10.4049/jimmunol.1000661

29. Krupnick AS, Lin X, Li W, Higashikubo R, Zinselmeyer BH, Hartzler H, et al. Central memory CD8+ T lymphocytes mediate lung allograft acceptance. $J$ Clin Invest (2014) 124:1130-43. doi:10.1172/JCI71359

30. Dai Z, Zhang S, Xie Q, Wu S, Su J, Li S, et al. Natural CD8+CD122+ T cells are more potent in suppression of allograft rejection than CD4+CD25+ regulatory T cells. Am J Transplant (2014) 14:39-48. doi:10.1111/ajt.12515

Conflict of Interest Statement: The authors declare that the research was conducted in the absence of any commercial or financial relationships that could be construed as a potential conflict of interest.

Copyright $\odot 2016$ Zeng, Lu and Dai. This is an open-access article distributed under the terms of the Creative Commons Attribution License (CC BY). The use, distribution or reproduction in other forums is permitted, provided the original author(s) or licensor are credited and that the original publication in this journal is cited, in accordance with accepted academic practice. No use, distribution or reproduction is permitted which does not comply with these terms. 